\title{
Supply-side biogeography: geographic patterns of settlement and early mortality for a barnacle approaching its range limit
}

\author{
Justin A. Lathlean*, David J. Ayre, Todd E. Minchinton \\ Institute for Conservation Biology \& School of Biological Sciences, University of Wollongong, New South Wales 2522, \\ Australia
}

\begin{abstract}
Species range limits are often associated with reduced adult densities, and this may reflect the failure of a particular life-history stage. For benthic marine invertebrates, settlement is a time of great mortality that strongly influences adult population structure, at least at local spatial scales. In south-eastern Australia we determined that adult abundance of the intertidal barnacle Tesseropora rosea declines over a $450 \mathrm{~km}$ region of rocky shore from the middle to the southern limit of its range, and we tested the hypothesis that this biogeographic pattern reflects variations in the production, settlement, or early post-settlement mortality of larvae or adult mortality. Sampling at 2 sites on 11 rocky shores in this region over 2 yr revealed that none of the life-history stages or demographic processes displayed a latitudinal gradient or a clear decline towards the south, and settlement and adult mortality were highly variable among locations. Indeed local variation in early lifehistory processes and adult mortality appears to dictate regional variability and observed latitudinal patterns of adult abundance of $T$. rosea, but longer term studies spanning at least a decade may determine if storage from one strong year in recruitment can set patterns of adult abundance.
\end{abstract}

KEY WORDS: Abundant-centre hypothesis · Early post-settlement mortality · Tesseropora rosea · Adult mortality · Geographic distribution · Latitudinal gradient

\section{INTRODUCTION}

Biogeographic theory predicts that the abundance of a species is generally greatest at the centre of its range and least at its edges (Brown 1984, Caughley et al. 1988, Sagarin \& Gaines 2002a,b). This 'abundantcentre hypothesis' has been supported for many species of terrestrial plants, with adult abundance declining towards their geographic range limits because physiological stress reduces reproductive output and survival (Pigott \& Huntley 1981, Parsons 1991, Woodward 1997, Dorken \& Eckert 2001, Jump \& Woodward 2003, Mathews \& Bonser 2005). As for terrestrial plants, many benthic marine invertebrates have sessile adults and dispersive propagules and, consequently, their geographic patterns of abundance might be expected to conform to abundant-centre distributions as a result of decreased larval supply and increased early post-settlement mortality of larvae from the centres to the edges of their range (Zacherl et al. 2003, Bahn et al. 2006, Gilman 2006a, b, Sanford et al. 2006). Dispersal in the ocean and recruitment variability into the benthic habitat is potentially much greater for benthic invertebrates than for most plants. However, the relatively few studies to date indicate that geographic patterns of adult abundance for benthic marine invertebrates generally do not reflect abundant-centre distributions (Sagarin \& Gaines 2002a).

For many benthic marine invertebrates with sessile adults and dispersive larvae, recruitment is a key demographic process structuring adult populations (Connell 1985, Gaines \& Roughgarden 1985, Minchinton \& Scheibling 1991, Caley et al. 1996, Hunt \& Scheibling 1997). Recruitment integrates the arrival, settlement and early post-settlement mortality of larvae (Thorson 1950, Keough \& Downes 1982) and, 
although these supply-side processes are often highly variable in space and time (see Underwood \& Fairweather 1989, Caley et al. 1996, Hunt \& Scheibling 1997), they sometimes reflect latitudinal gradients of temperature, currents, wave exposure and nutrient availability in the ocean (Connolly \& Roughgarden 1998, Connolly et al. 2001, Zacherl et al. 2003, Sanford et al. 2006). Consequently, the geographic distribution of benthic marine invertebrates, particularly as a species approaches its range limit, may be strongly influenced by latitudinal gradients in the supply and early life history of larvae. Alternatively, processes operating at more local scales in the post-recruitment environment (e.g. storm events, habitat, microclimates, predation) could override larger scale patterns of recruitment that might determine geographic patterns in adult abundance (Helmuth 1998). Measuring settlement and early post-settlement mortality of benthic marine invertebrates is often difficult, however, because larvae are small and often die soon after settlement. Few studies have measured these early lifehistory processes simultaneously across large geographic scales (but see Caffey 1985, Connolly et al. 2001, Hughes et al. 2002), but such studies can yield important insights into the processes setting the range limits of species.

Along the linear coastline of south-eastern Australia, there is great potential for the population size of sessile marine invertebrates with planktonically dispersing larvae to decline with increasing latitude. First, the unidirectional East Australian Current (EAC) runs north to south along the east coast of Australia, and then weakens and deflects away from the coast at the south-eastern corner of the mainland (Knox 1963, Huyer et al. 1988, O'Hara \& Poore 2000, Oke \& Middleton 2001, Roughan \& Middleton 2004). Second, seawater and air temperatures decline with the transition from subtropical to temperate regions with increasing latitude. Together, these latitudinal variations in oceanographic conditions and potential physiological stresses in the benthic habitat are predicted to reduce the fecundity of adults, increase the early post-settlement mortality of early juveniles and diminish reliability in the supply of larvae from northern to southern populations (Murray-Jones \& Ayre 1997, Hidas et al. 2007). Indeed, due to the absence of small individuals in southern locations, Hidas et al. (in press) suggest recruitment events are less frequent for the intertidal barnacle Tesseropora rosea (Krauss) towards its southern range limit.

Here we investigate whether a latitudinal gradient of recruitment drives the adult population structure of the intertidal barnacle Tesseropora rosea, a species that disperses via planktonic larvae and, furthermore, shows adult abundances consistent with an abundant- centre distribution, with declines from the middle to the southern limit of its range at the south-eastern corner of mainland Australia (Hidas et al. in press). The only study to have assessed the large-scale patterns of settlement and early post-settlement mortality for $T$. rosea found no latitudinal trends in recruitment; however, only populations within the middle of its geographic range were examined (Caffey 1985). We measured the fecundity of adults and the settlement and early post-settlement mortality of larvae (i.e. recruitment) for a cohort of $T$. rosea on rocky intertidal shores spanning $450 \mathrm{~km}$ of coastline to determine how geographic variation in these demographic processes was related to the patterns of abundance of individuals within the cohort surviving to adulthood at the end of that year. We predicted that a combination of reduced larval production, settlement and increased early postsettlement mortality of larvae from north to south accounts for the latitudinal decline in the abundance of T. rosea adults as they approach their southern range limit. We also monitored the recruitment into and mortality of adult populations for $2 \mathrm{yr}$, to determine how local or geographic variation in these processes might account for the latitudinal gradient in population size.

\section{MATERIALS AND METHODS}

Study region and species. We monitored the production, settlement and early post-settlement mortality of larvae and the mortality of adults of the intertidal barnacle Tesseropora rosea from February 2007 to December 2008 in mid-shore regions at 2 sites on 11 rocky shores along the south-eastern coast of Australia. Rocky shore locations extended from Garie Beach, south of Sydney, New South Wales $\left(34^{\circ} 09^{\prime} S\right.$, $\left.151^{\circ} 04^{\prime} \mathrm{E}\right)$, in the middle of the geographic range of $T$. rosea, to Mallacoota, Victoria $\left(37^{\circ} 34^{\prime} \mathrm{S}, 149^{\circ} 45^{\prime} \mathrm{E}\right)$, at its southern range limit (Bennett \& Pope 1953, Edgar 2008) (Fig. 1). Occasionally, individuals of T. rosea are found in central Victoria (Jones 1990), but they do not persist, probably due to colder environmental conditions. The rocky shores were selected to have the same rock type (sandstone), degree of wave exposure (moderate to exposed), slope (gradually sloping platforms) and aspect (facing east to southeast) to ensure abiotic conditions such as substratum, hydrodynamic processes and exposure to sunlight remained equivalent amongst locations. In situ data loggers (Onset TidbiT v2 Temp logger), recording air and water temperatures every $10 \mathrm{~min}$, were deployed within the mid-shore region at both Garie Beach and Mallacoota (i.e. the most northern and southern locations, respectively) and confirmed that a temperature gradient exists across the study region, with the maximum (air: $50.8^{\circ} \mathrm{C}_{i}$ water: 


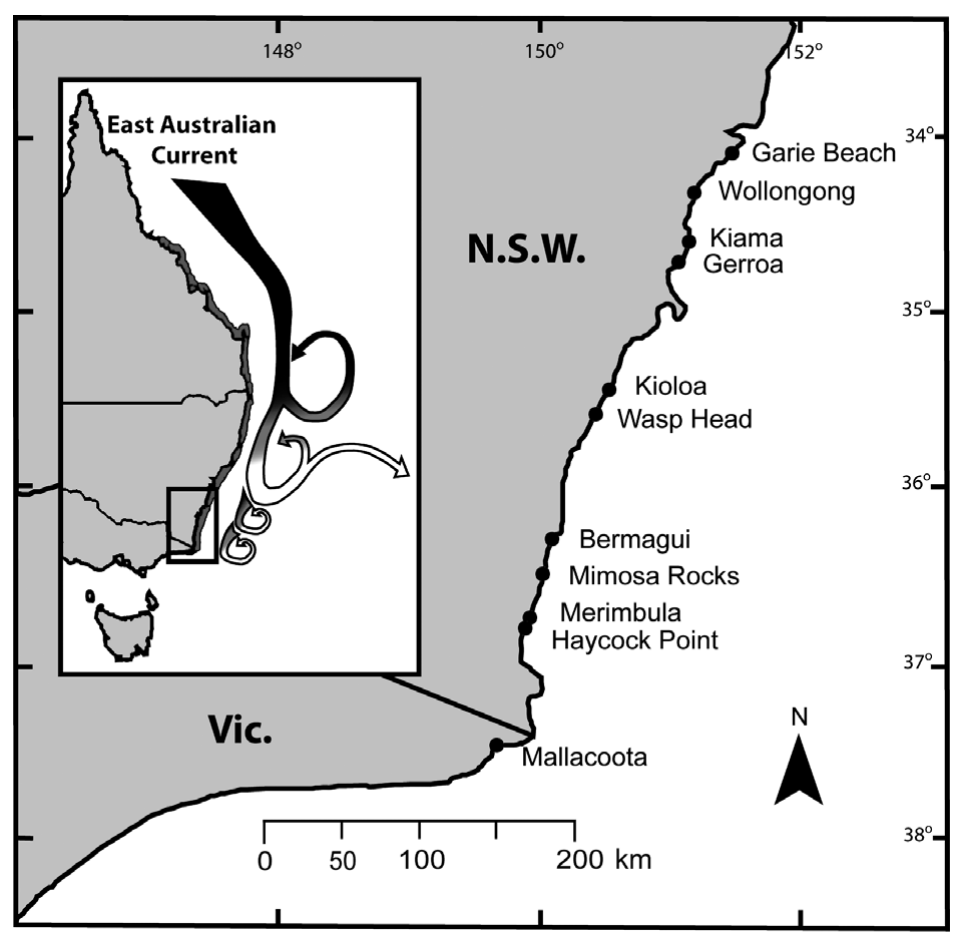

Fig. 1. Coast of south-eastern Australia showing sampling locations separated by 10 to $80 \mathrm{~km}$. Inset shows the geographic range of Tesseropora rosea (shaded area) and the Eastern Australian Current, with shading from black to white representing strong to weak influence

nauplii (Embryo Stage V) (Anderson 1969). From our observations embryo development in the mantle cavity is relatively synchronised so that the majority of embryos reach maturity at approximately the same time. We therefore scored individuals as being mature, if eyed nauplii were present in the mantle cavity, or developing, if embryos were present but immature (Stages II to IV) (Anderson 1969; see further details below).

Sampling design and variables. At each rocky shore location, we established 2 sites that extended $30 \mathrm{~m}$ alongshore and were separated by 10 to $30 \mathrm{~m}$. At each site, 30 permanent quadrats of $10 \times 10 \mathrm{~cm}$ were randomly located within the mid-shore region characteristically dominated by Tesseropora rosea ( 0 to $1.6 \mathrm{~m}$ above the mean low water mark of neap tides: MLWN). Quadrats were positioned on horizontal to slightly sloping surfaces and separated by 0.5 to $1 \mathrm{~m}$. A stainless steel screw was drilled into the centre of each quadrat to ensure that they could be accurately resampled over time.

We tracked individual barnacles in these 30 quadrats over time using digital photographs taken with a high-resolution digital camera (Fujifilm S9600), and comparisons of in situ counts and photographs showed

26. $4^{\circ} \mathrm{C}$ ) and minimum (air: $5^{\circ} \mathrm{C}$; water: $14.2^{\circ} \mathrm{C}$ ) temperatures at Garie Beach being greater than the maximum (air: $42.3^{\circ} \mathrm{C}$; water: $22.4^{\circ} \mathrm{C}$ ) and minimum (air: $3.8^{\circ} \mathrm{C}$; water: $12.3^{\circ} \mathrm{C}$ ) temperatures at Mallacoota recorded continuously between December 2007 and December 2008.

Adult Tesseropora rosea are hermaphroditic and brood plantivorous larvae that are released predominantly from January to June, with the larvae estimated to remain within the water column for approximately 13 d (Wisely \& Blick 1964, Anderson \& Buckle 1983, Egan \& Anderson 1988). Although larval settlement may occur throughout the year, the vast majority settle between January and July with 2 peaks, one during January and February and then a second during May and June, with the peak in January to February generally being more prominent at northern locations, and vice versa for more southern locations (Caffey 1985). We found that recently settled $T$. rosea grow quickly and become reproductively mature 2 to 3 mo after settlement, with some individuals with aperture lengths as small as $1.5 \mathrm{~mm}$ possessing either gonads or mature or developing embryos (but see Egan \& Anderson 1988). Fertilization is internal and larvae are brooded within the mantle cavity until they are ready to be released. Mature embryos are recognised as eyed this method to be accurate (Lathlean unpubl. data). We photographed each quadrat monthly (February to July 2007) during the main period of settlement for Tesseropora rosea (see Wisely \& Blick 1964, Caffey 1985), then approximately quarterly until December 2008 (i.e. August and December 2007; February, May, August and December 2008). Recently settled T. rosea (individuals $<1$ wk old) could not always be distinguished from recently settled individuals of the barnacle Catomerus polymerus, but C. polymerus recruits (individuals $>1$ mo old) were rarely observed, and constituted $<1 \%$ of the total number of barnacle recruits; therefore, any misidentification is unlikely to influence results.

Geographic patterns of demography and population structure. During 2007, settlement, recruitment and adult density at each site were determined in separate quadrats, with 10 of the 30 quadrats randomly assigned to 1 of 3 treatments: 'recleared' quadrats were cleared of all Tesseropora rosea at each sampling time and used to estimate settlement, 'cumulative' quadrats were cleared initially and then allowed to accumulate $T$. rosea recruits and were used to estimate recruitment and 'untouched' quadrats were not cleared at any time and were used to estimate adult density (see details below). From these estimates of 
abundance, mortality at each life-history stage (early post-settlement mortality, post-recruitment mortality, adult mortality) was calculated (see details below). This approach differed somewhat from that used by Caffey (1985) in that we did not alternatively clear quadrats once every $2 \mathrm{mo}$. In doing so we were able to estimate the percentage of recruits surviving for $>2 \mathrm{mo}$ and assess the likelihood that these recruits reach reproductive maturity and contribute to the size of the adult population.

Settlement at a site was estimated by counting the number of recently settled Tesseropora rosea, as well as any empty tests from recent deaths of settlers, in the 10 'recleared' quadrats. To ensure that we counted only recently settled individuals, recleared quadrats were cleared of all organisms at the start of the study in February 2007 and then again after each census. A metal brush was also used to remove any existing layer of biofilm within these recleared quadrats at each census. This may have caused us to potentially underestimate settlement, as settlement increases with the amount and age of biofilm (Qian et al. 2003, Thiyagarajan et al. 2006; but see Olivier et al. 2000), but was necessary to remove any confounding effects of increased amounts of biofilm within southern locations where adult densities were lower. Therefore, because we sampled only once per month, our 'settlers' could be 1 to $30 \mathrm{~d}$ old. Undoubtedly, at this sampling frequency we missed some individuals that settled and died before they could be counted, and this could have resulted in an underestimation of the absolute magnitude of settlement and early mortality (see Minchinton \& Scheibling 1993). Nevertheless, Caffey (1985) found that for this species this frequency suitably differentiated settlement from recruitment. Settlement at a site was calculated as the sum of the number of $T$. rosea that settled in each of the 10 recleared quadrats for all months between February and December 2007.

Recruitment at a site was estimated in the 10 'cumulative' quadrats. These quadrats were cleared of all organisms once, in February 2007, and then settling barnacles were allowed to accumulate for the entire 2 yr sampling period. Recruitment at a site was calculated by summing the peak, or maximal, number of Tesseropora rosea recruits (i.e. individuals $>30 \mathrm{~d}$ old) recorded within each of the 10 cumulative quadrats at any sampling interval between February and December 2007. Early post-settlement mortality was calculated as the percentage difference between settlement and recruitment. Likewise, post-recruitment mortality was calculated as the percentage difference between recruitment and the number of $T$. rosea remaining within cumulative quadrats in December 2007.

Adult density at a site was calculated as the sum of the number of Tesseropora rosea adults (i.e. individuals with an aperture length of $>1.5 \mathrm{~mm}$ ) within each of the 10 untouched quadrats in December 2007. Maximal adult density at a site was calculated as the sum of the maximal number of $T$. rosea adults recorded within each of the 10 untouched quadrats between February and December 2007. Adult mortality at a site was calculated as the percentage difference between 'maximal' adult density and adult density in December 2007.

Following the methods of Egan \& Anderson (1988), the potential for larval production at each location was determined by quantifying the percentage of adults with developing (creamy to bright yellow coloured embryos) or mature, ready-to-spawn (i.e. brown-eyed nauplii) larvae over time (Wisely \& Blick 1964, Egan \& Anderson 1988). Quantitative assessment of fecundity proved difficult because mantle cavities were often damaged when adults were prised from the substratum for examination. We collected at least 40 adult Tesseropora rosea (i.e. individuals with an aperture length of $>1.5 \mathrm{~mm}$ ) once per month during the main breeding season (i.e. February to July 2007), then again in August and December 2007, from areas outside the permanent quadrats and spread across both sites at each location. Adults were preserved, transported to the laboratory and the presence of developing larvae was assessed using a dissecting microscope. The proportion of adults at each location with either mature or developing larvae was calculated for all adults sampled over the entire year.

Changes to population structure. We monitored latitudinal changes in population structure by comparing densities of Tesseropora rosea within both the cumulative and untouched quadrats at each site at the beginning of the sampling period in February 2007 and again in both December 2007 and 2008. This allowed us to determine whether recruitment processes (i.e. settlement and post-settlement mortality within cumulative quadrats) would return each population to its former abundance, or whether the adult population abundance initially observed persists through time (i.e. untouched quadrats).

Statistical analysis. We expected substantial variation among quadrats at a site, and, given that our aim here was to determine how demographic and population parameters varied with latitude, we pooled densities of settlers, recruits and adults among recleared, cumulative and untouched quadrats, respectively, to yield 1 estimate of each for each site (i.e. $\mathrm{n}=2$ sites location $^{-1}$ ). Due to extreme weather events and ephemeral algae or sand obscuring quadrats, we were unable to sample all sites in each month. For the months when sites were covered by sand, we assumed new settlers and recruits would have died, and, therefore, we assigned values of zero for such months (and subsequent observations showed that this was gener- 
ally the case). For months when sites could not be sampled due to bad weather or were obscured by algae, we excluded such months and sampled as previously described for the following months. This did not occur often, with only $7.8 \%$ of the sites not being sampled during the entire $2 \mathrm{yr}$ sampling period. Larval production, settlement, recruitment, early post-settlement mortality, post-recruitment mortality, adult mortality and adult densities were correlated with latitude to test for the presence of latitudinal gradients.

We used 1-way ANOVAs to test for heterogeneity of (1) settlement, (2) recruitment, (3) early postsettlement mortality, (4) early post-recruitment mortality, (5) adult mortality and (6) adult density across the 11 locations. Where significant differences were found, a Student-Neuman-Keuls (SNK) test was used to determine which locations had significantly different settlement, recruitment, early post-settlement mortality, postrecruitment mortality, adult mortality, or adult densities. We confirmed that the data were approximately normally distributed and showed equal variance using the Shapiro-Wilks' and Cochran's test, respectively.

\section{RESULTS}

\section{Geographic patterns of demography}

The vast majority of adult Tesseropora rosea brooded developing and mature embryos at all locations throughout the range, but the proportion of adults with eyed nauplii did not vary across the geographic range or show any significant relationship to latitude $\left(r^{2}=0.052, n=10, p=0.501\right.$; Fig. 2a).

Settlement at most locations was typically derived from single, large pulses of larvae settling on shore sporadically from late summer to late autumn. Indeed, although not significantly different, densities of settlers varied greatly between sites at a location and by more than an order of magnitude among locations $\left(F_{10,11}=\right.$ $2.37, p=0.086)$, and there was no significant relationship between settlement and latitude $\left(\mathrm{r}^{2}=0.013, \mathrm{n}=\right.$ $21, p=0.613$; Fig. 2b).

There was great early post-settlement mortality at all locations, with an average of $79.4 \%$ of newly settled Tesseropora rosea dying by December 2007 (Fig. 2c), and, as for settlement, no latitudinal decline in early post-settlement mortality was detected $\left(\mathrm{r}^{2}=0.005, \mathrm{n}=\right.$ $21, p=0.752$ ). Densities of recruits varied significantly among locations $\left(F_{10,11}=3.20, \mathrm{p}=0.035\right)$, with an SNK test indicating that the number of recruits at Mimosa Rocks was greater than that at all other locations (Fig. 2d). Interestingly, recruitment of T. rosea was largely reflective of settlement, as locations that received large numbers of settlers generally had a
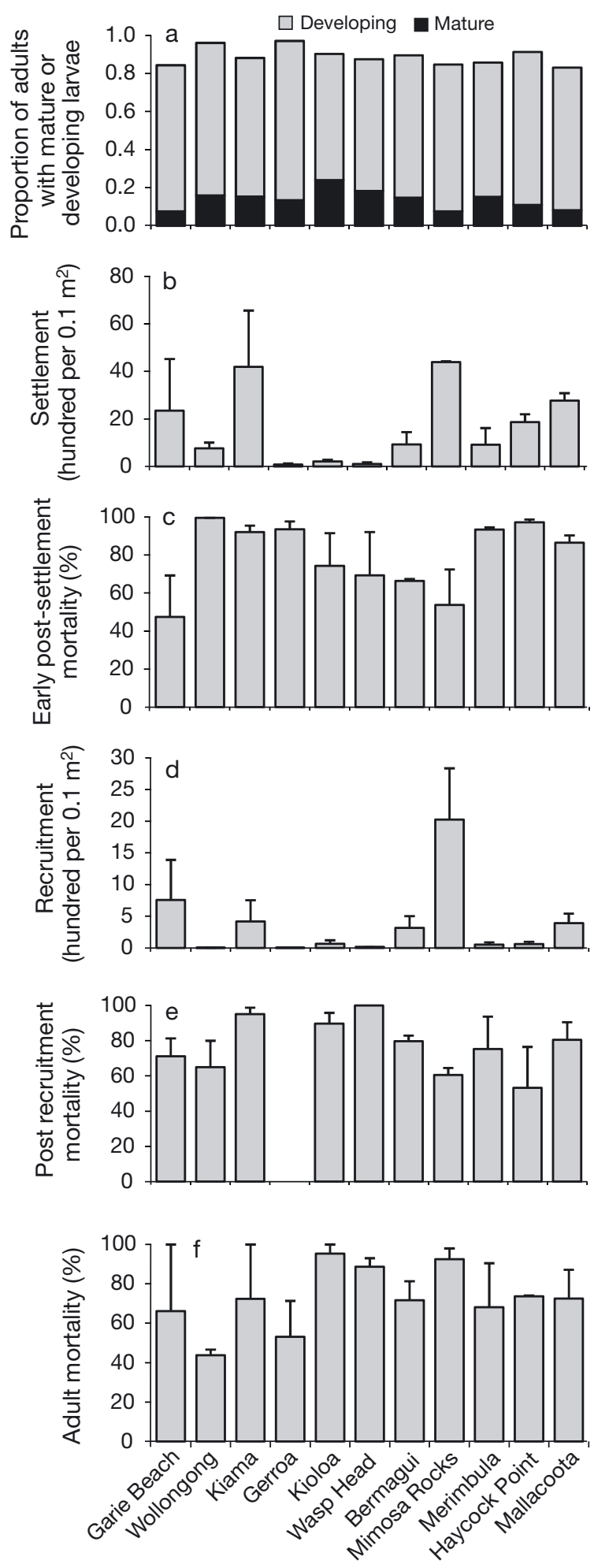

Fig. 2. Tesseropora rosea. Latitudinal variation in (a) proportion of adults with either mature or developing larvae, (b) mean settlement, (c) mean percentage mortality of recently settled individuals, (d) mean recruitment, (e) mean post-recruitment mortality and (f) mean percentage adult mortality during 2007. Error bars represent standard errors due to variation between pairs of sites at each location 
larger number of recruits. For example, Mimosa Rocks received the greatest number of settlers and subsequently had the greatest number of recruits (Fig. 2b,d). Additionally, though not as great as early post-settlement mortality, post-recruitment mortality was also great and varied significantly among locations $\left(F_{10,11}=\right.$ 5.86, p = 0.004), with an average of $70 \%$ of recruits dying by December 2007, with a SNK test finding substantially lower mortality at Gerroa, Haycock Point and Mimosa Rocks (Fig. 2e).

Adult mortality was substantial at all locations, with on average $72.5 \%$ of adult barnacles dying during 2007 (Fig. 2f). Nevertheless, adult mortality was highly variable between sites and not significantly different among locations $\left(F_{10,11}=0.857, \mathrm{p}=0.953\right)$, being greatest at Kioloa (95.3\%) and least at Wollongong (43.7\%). Similar to larval production, settlement, early post-settlement mortality, recruitment and post-recruitment mortality, no latitudinal gradient was found for adult mortality $\left(\mathrm{r}^{2}=0.07, \mathrm{df}=21, \mathrm{p}=0.231\right)$.

\section{Changes to population structure}

There was a significant linear relationship between the density of adult Tesseropora rosea and latitude at the start of sampling in February 2007, with adult abundance in untouched quadrats declining substantially from the middle to the edge of its range $\left(\mathrm{r}^{2}=0.36\right.$, $\mathrm{n}=21, \mathrm{p}=0.003$; Fig. 3). But, as a result of the consistently high and variable early post-settlement mortality post-recruitment mortality and adult mortality, by the end of sampling in December 2008 there was no latitudinal gradient in adult abundance within either untouched $\left(\mathrm{r}^{2}=0.17, \mathrm{n}=21, \mathrm{p}=0.054\right)$ or cumulative quadrats $\left(r^{2}=0.028, n=21, p=0.455\right)$, suggesting the original latitudinal decline in adult abundance neither persists nor becomes re-established in time (Fig. 3). Indeed, there were no latitudinal patterns for any demographic process examined, with local variability in adult mortality appearing to drive geographic patterns of adult abundance.

\section{DISCUSSION}

At the start of the study, populations of the rocky shore barnacle Tesseropora rosea displayed abundantcentre patterns of geographic distribution (see also Hidas et al. in press), with an inverse relationship between density and latitude from the middle to the southern limits of its range. Contrary to expectations, however, we detected no latitudinal gradients in the key demographic processes expected to contribute to

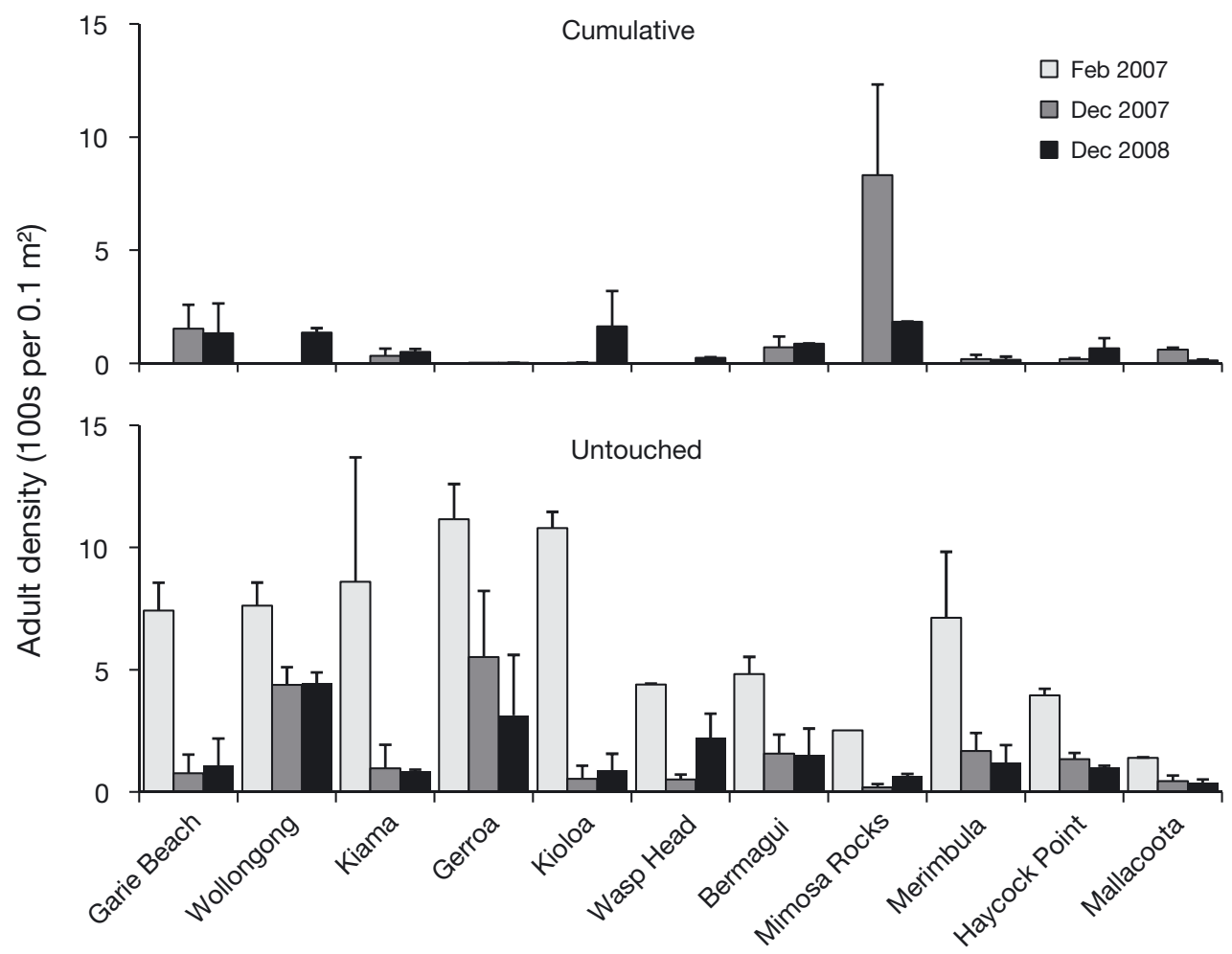

Fig. 3. Tesseropora rosea. Latitudinal variation in density for both cumulative and untouched treatments in February and December 2007 and December 2008. Error bars represent standard errors due to variation between pairs of sites at each location 
this pattern, including larval production, settlement, early post-settlement mortality, or recruitment. Indeed, it appears that variations in recruitment and adult mortality due to local forces might make the greatest contribution to geographic patterns of abundance and apparent latitudinal trends.

Larval production was relatively uniform among locations, suggesting that the reduction in seawater and air temperatures towards the southern range limit does not limit the ability of Tesseropora rosea to produce larvae. This is perhaps surprising because studies have shown that such differences in seawater temperatures can influence the reproductive ability of benthic marine invertebrates (Brey 1995, Vilchis et al. 2005), and field investigations have detected reduced fecundity at range limits due to changes in seawater temperature (Barber \& Blake 1983, Amaro et al. 2005). However, Helmuth et al. (2006) assessed body temperatures of the intertidal mussel Mytilus californianus across a latitudinal gradient in sea-surface temperatures and found that body temperatures were often hotter or colder than was predicted from sea-surface temperatures. Consequently, the lack of a latitudinal decline in larval production within the present study may reflect complex interactions between air and seasurface temperatures. Larval production has also been shown to be directly associated with food availability (Leslie et al. 2005). Therefore, more quantitative sampling of larval production could reveal differences among locations that either experience different air or sea temperatures or food concentrations. Similarly, we expected the reduction in seawater temperatures towards the southern range limit of $T$. rosea to reduce larval settlement and increase early mortality (Gaylord \& Gaines 2000, Sprung 2001, Zacherl et al. 2003). Instead, settlement was largely sporadic and unpredictable, with locations separated by hundreds of kilometres simultaneously receiving large pulses of newly settled T. rosea, while adjacent locations received relatively few settlers. This supports work by Caffey (1985), who found highly variable settlement of $T$. rosea at large spatial scales and no clear latitudinal trend for this species in the central region of its geographic distribution.

The lack of latitudinal trends in the production and settlement of larvae suggests that populations in the middle and edge of the range receive similar levels of larval supply and settlement success (Hughes et al. 2002). This contrasts with expectations that larval supply would be reduced as Tesseropora rosea approaches its southern range limit, due to a combination of reduced larval production and increasingly unreliable larval transport by the East Australian Current from north to south. Indeed, there is no evidence indicating that recruitment limitation, either through limited larval supply and settlement or increased early mortality, influences local populations at the southern range limit of $T$. rosea (but see Hidas et al. in press).

Early post-settlement mortality of Tesseropora rosea was found to be consistently high among all locations and was on average $79 \%$, which is considerably higher than the average of $66.5 \%$ detected by Caffey (1985). Likewise, the adult mortality among all locations was extremely high for a 1 yr period when compared to similar studies undertaken over shorter sampling periods (Denley \& Underwood 1979, Caffey 1985, Jernakoff 1985, Otway \& Underwood 1987). For example, Otway \& Underwood (1987) found adult mortality of T. rosea to vary between only 14 and $18 \%$ over 13 mo, while Jernakoff (1985) found adult mortality to vary between 0.5 and $2.5 \%$ over a 3 mo period. Numerous factors such as biological and physical disturbances, physiological stress, predation and competition are known to influence the mortality of newly settled benthic marine invertebrates at small spatial scales (for review see Hunt \& Scheibling 1997). For T. rosea specifically, the major causes of early postsettlement mortality are algal growth, 'bulldozing' by grazing limpets and intraspecific competition (Denley \& Underwood 1979, Underwood et al. 1983, Jernakoff 1985), with the predatory whelks Morula marginalba and Dicathais orbita being the most likely causes of adult mortality (Underwood et al. 1983, Fairweather et al. 1984, Moran 1985). However, whether predation by M. marginalba and $D$. orbita continues to influence populations over large spatial scales has yet to be determined. In addition, it is unlikely that interspecific competition between $T$. rosea and Catomerus polymerus, another intertidal barnacle more commonly found in the southern parts of Australia, contributed to the high levels of early post-settlement mortality and adult mortality of $T$. rosea documented in the present study as: (1) larval settlement between these 2 species occurs at different times of the year (Wisely \& Blick 1964), (2) C. polymerus abundance was generally low and (3) free space did not appear to be a limiting factor in southern locations where densities of C. polymerus were somewhat greater. However, further research is required to understand what role, if any, competition between $T$. rosea and $C$. polymerus plays in determining the southern range limit of $T$. rosea.

Latitudinal gradients in settlement and recruitment may be attributed to differential coastal upwelling, as increased upwelling reduces larval concentrations within coastal waters and subsequently reduces settlement as more larvae are transported offshore, limiting contact with their preferred substrata (Gaines et al. 1985, Roughgarden et al. 1988, Connolly et al. 2001, Menge et al. 2004). Consequently, the highly variable patterns of settlement detected within the present study could reflect variable upwelling along the south- 
eastern coast of Australia (Roughan \& Middleton 2004) and geographical variation in topographic features that assist in retaining larvae (Jenkins \& Hawkins 2003, Mace \& Morgan 2006). However, since many oceanographic studies have revealed only weak upwelling along this coast (Roughan \& Middleton 2004), it is unlikely that variable upwelling is the only contributing factor to variable settlement. This highly variable settlement could also suggest that larval physiological condition varies significantly within the study region as recent studies have shown larval condition, which can be determined by variable temperature and food concentrations (Desai \& Anil 2004), to strongly influence the settlement (Thiyagarajan et al. 2002, Tremblay et al. 2007) and early post-settlement growth and survival (Thiyagarajan et al. 2005, Emlet \& Sadro 2006) of larvae. Therefore, local processes may be equally important as regional processes in setting the patterns of adult abundance and potentially the geographic distribution and southern range limit of Tesseropora rosea.

The absence of latitudinal gradients in larval production, settlement, early post-settlement and adult mortality suggest that these life-history processes are not responsible for the latitudinal decline in adult abundance or the southern range limit of Tesseropora rosea. However, the exceptionally high mortalities of both recently settled and adult $T$. rosea significantly reduced adult densities such that, by the final census, adult densities no longer declined towards the southern range limit, suggesting an exceptionally large disturbance had occurred, obscuring important relationships. Indeed, the shift from an El Niño to a La Niña pattern during 2007 may have attributed to several atypical oceanographic features, including 4 unusually large consecutive low pressure systems crossing the Tasman Sea in June 2007, causing strong, predominantly southerly swells over the study area, at times in excess of $7 \mathrm{~m}$ (Australian Bureau of Meteorology 2007). Increased sand scour caused by such an oceanographic regime would presumably have had a significant impact on large-scale patterns of settlement, early post-settlement and adult mortality of $T$. rosea. Such large southerly swells are seasonally common during winter along the south-eastern coast of Australia (Short \& Trenaman 1992). Therefore, T. rosea recruits may experience increased mortality during winter each year, with survival favouring earlier settling individuals that managed to reach a specific size. Alternatively, the average life expectancy of adult $T$. rosea is only 4 yr (Caffey 1985), and consequently, the high adult mortality detected in the present study may be reflective of the senescence of a large cohort that gave rise to the initial latitudinal decline in adult abundance simultaneously dying off. However, adult mortality appeared to occur irrespective of size or age, suggesting mortality was high across several cohorts within each location. Regardless, demographic processes operating over 2 yr have greatly influenced the population structure of $T$. rosea, suggesting that infrequent events could potentially have longer lasting impacts than patterns of settlement, early post-settlement and adult mortality combined over numerous years.

Geographic patterns of adult abundance might of course reflect environmental cycles with longer periodicity than most studies, including this one. For example, geographic patterns might develop over time due to changing environmental conditions, such as the prolonged El Niño conditions in south-eastern Australia from 2001 to 2006 (Australian Bureau of Meteorology 2007), influencing demographic processes gradually. Alternatively, observed patterns of decreasing adult abundances with latitude might reflect 'stored' patterns determined by a year of great recruitment combined with different environmental conditions to those observed during the present study. Such large recruitment events appear to be common for Tesseropora rosea and might lock in latitudinal patterns of adult abundance for the lifespan of the species, which can be 10 yr (Denley 1981, Caffey 1985). Only massive mortality, such as that observed in the present study, might disrupt such geographic trends. Clearly longer term observations are needed in both cases; importantly, however, the results here indicate that such latitudinal patterns are dynamic. The great variability in settlement and early mortality over geographic scales observed here suggest that, for sessile marine invertebrates with planktonic dispersing larvae, factors that act on a local scale (e.g. recruitment, mortality, natural disturbance) might be more important in setting geographic patterns of distributions than differences in larval supply, settlement and early mortality with latitude.

\section{CONCLUSIONS}

The latitudinal decline in adult abundance of Tesseropora rosea towards its southern range limit does not appear to be governed by latitudinal gradients in early life-history processes or adult mortalities. Therefore, either processes affecting the life-history stages of $T$. rosea do not influence the abundance at its southern range limit, or these life-history processes must be extremely variable between years such that: (1) large-scale patterns of larval production, settlement, early post-settlement and adult mortality during a single year dictate demographic patterns for numerous years or (2) the combined affect of life-history processes over numerous years determines large-scale demographic variability. Regardless, it is evident that 
more long-term, large-scale studies are required to confidently conclude which processes determine the southern range limit of $T$. rosea and the range limits of benthic marine invertebrates in general.

Acknowledgements. We thank Laura Attrill, Aidan Johnson, Eszter Hidas, Lucia Aguilar, Alison Broad, Zoe Diment and Sascha Schulz for assistance in the field and David Roberts, who provided helpful constructive comments on the manuscript. This research was supported under Australian Research Council's 'Discovery Project' funding scheme (Project Number DP0666787) through a grant to D. J. A. and T. E. M., a University of Wollongong post-graduate scholarship to J. A. L. and by the Institute for Conservation Biology at the University of Wollongong.

\section{LITERATURE CITED}

Amaro T, Duineveld G, Tyler P (2005) Does Mya truncata reproduce at its southern distribution limit? Preliminary information. J Shellfish Res 24:25-28

Anderson DT (1969) On the embryology of the cirripede crustaceans Tetraclita rosea (Krauss), Tetraclita purpurascens (Wood), Chthamalus antennatus (Darwin) and Chamaesipho columna (Spengler) and some considerations of crustacean phylogenetic relationships. Philos Trans R Soc Lond, B 256:183-235

Anderson DT, Buckle J (1983) Cirral activity and feeding in the coronuloid barnacles Tesseropora rosea (Krauss) and Tetraclitella purpurascens (Wood) (Tetraclitidae). Bull Mar Sci 33:645-655

Australian Bureau of Meteorology (2007) Radar images: Australian weather watch radar. Bureau of Meteorology, Melbourne. Available at: www.bom.gov.au/australia/charts/ (accessed July 2007)

Bahn V, O'Connor RJ, Krohn WB (2006) Effect of dispersal at range edges on the structure of species ranges. Oikos 115: 89-96

Barber BJ, Blake NJ (1983) Growth and reproduction of the bay scallop Argopecten irradians at its southern distributional limit. J Exp Mar Biol Ecol 66:247-256

Bennett I, Pope E (1953) Intertidal zonation of the exposed rocky shores of Victoria, together with a rearrangement of the biogeographical provinces of temperate Australian shores. Aust J Mar Freshw Res 4:105-159

$>$ Brey $\mathrm{T}$ (1995) Temperature and reproductive metabolism in macrobenthic populations. Mar Ecol Prog Ser 125:87-93

$>$ Brown JH (1984) On the relationship between abundance and distribution of species. Am Nat 124:255-279

> Caffey HM (1985) Spatial and temporal variation in settlement and recruitment of intertidal barnacles. Ecol Monogr 55:313-332

- Caley MJ, Carr MH, Hixon MA, Hughes TP, Jones GP, Menge BA (1996) Recruitment and the local dynamics of open marine populations. Annu Rev Ecol Syst 27:477-500

Caughley G, Grice D, Barker R, Brown B (1988) The edge of the range. J Anim Ecol 57:771-785

Connell JH (1985) The consequences of variation in initial settlement vs. post-settlement mortality in rocky intertidal communities. J Exp Mar Biol Ecol 93:11-45

> Connolly SR, Roughgarden J (1998) A latitudinal gradient in intertidal community structure: evidence for an oceanographically based synthesis of marine community theory. Am Nat 151:311-326

Connolly SR, Menge BA, Roughgarden J (2001) A latitudinal gradient in recruitment of intertidal invertebrates in the northeast pacific ocean. Ecology 82:1799-1813

Denley EJ (1981) The ecology of the intertidal barnacle, Tesseropora rosea. Dissertation, University of Sydney, Sydney

> Denley EJ, Underwood AJ (1979) Experiments on factors influencing settlement, survival, and growth of two species of barnacles in New South Wales. J Exp Mar Biol Ecol 36:269-293

- Desai D, Anil AC (2004) The impact of food type, temperature and starvation on larval development of Balanus amphitrite Darwin (Cirripedia: Thoracica). J Exp Mar Biol Ecol 306:113-137

> Dorken ME, Eckert CG (2001) Severely reduced sexual reproduction in northern populations of a clonal plant, Decodon verticillatus (Lythraceae). J Ecol 89:339-350

Edgar GJ (2008) Australian marine life: the plants and animals of temperate waters. New Holland, Sydney

Egan EA, Anderson DT (1988) Larval development of the coronuloid barnacles Austrobalanus imperator (Darwin), Tetraclitella purpurascens (Wood) and Tesseropora rosea (Krauss) (Cirripedia, Tetraclitidae). J Nat Hist 22: 1379-1405

Emlet RB, Sadro SS (2006) Linking stages of life history: how larval quality translates into juvenile performance for an intertidal barnacle (Balanus glandula). Integr Comp Biol 46:334-346

Fairweather PG, Underwood AJ, Moran MJ (1984) Preliminary investigations of predation by the whelk Morula marginalba. Mar Ecol Prog Ser 17:143-156

Gaines S, Roughgarden J (1985) Larval settlement rate: a leading determinant of structure in an ecological community of the marine intertidal zone. Proc Natl Acad Sci USA 82:3707-3711

Gaines SD, Brown S, Roughgarden J (1985) Spatial variation in larval concentrations as a cause of spatial variation in settlement for the barnacle, Balanus glandula. Oecologia 67:267-272

> Gaylord B, Gaines SD (2000) Temperature or transport? Range limits in marine species mediated solely by flow. Am Nat 155:769-789

Gilman SE (2006a) The northern geographic range limit of the intertidal limpit Collisella scabra: a test of performance, recruitment, and temperature hypothesis. Ecography 29: 709-720

Gilman SE (2006b) Life at the edge: an experimental study of a poleward range boundary. Oecologia 148:270-279

Helmuth B (1998) Intertidal mussel microclimates: predicting the body temperature of a sessile invertebrate. Ecol Monogr 68:51-74

Helmuth B, Broitman BR, Blanchette CA, Gilman S and others (2006) Mosaic patterns of thermal stress in the rocky intertidal zone: implications for climate change. Ecol Monogr 76:461-479

Hidas EZ, Costa T, Ayre DJ, Minchinton TE (2007) Is the species composition of rocky intertidal invertebrates across a biogeographic barrier in south-eastern Australia related to their dispersal? Mar Freshw Res 58:835-842

Hidas EZ, Ayre DJ, Minchinton TE (in press) Patterns of demography for rocky invertebrates approaching their geographical range limits: tests of the abundant-centre hypothesis in southeast Australia. Mar Freshw Res

Hughes TP, Baird AH, Dinsdale EA, Harriott VJ and others (2002) Detecting regional variation using meta-analysis and large-scale sampling: latitudinal patterns in recruitment. Ecology 83:436-451

Hunt HL, Scheibling RE (1997) Role of early post-settlement 
mortality in recruitment of benthic marine invertebrates. Mar Ecol Prog Ser 155:269-301

Huyer A, Smith RL, Stabeno PJ, Church JA, White NJ (1988) Currents off south-eastern Australia: results from the Australian coastal experiment. Aust J Mar Freshw Res 39: 245-288

- Jenkins SR, Hawkins SJ (2003) Barnacle larval supply to sheltered rocky shores: A limiting factor? Hydrobiologia 503: $143-151$

Jernakoff P (1985) The effect of overgrowth by algae on the survival of the intertidal barnacle Tesseropora rosea Krauss. J Exp Mar Biol Ecol 94:89-97

Jones DS (1990) Occurrence of the barnacle Tesseropora rosea (Krauss) (Thoracica, Balanomorpha, Tetraclitidae) in western Australian waters. Rec West Aust Mus 14:665-668

$>$ Jump AS, Woodward FI (2003) Seed production and population density decline approaching the range-edge of Cirsium species. New Phytol 160:349-358

Keough MJ, Downes BJ (1982) Recruitment of marine invertebrates: the role of active larval choices and early mortality. Oecologia 54:348-352

Knox GA (1963) The biogeography and intertidal ecology of the Australasian coasts. Oceanogr Mar Biol Annu Rev 1: 341-404

> Leslie HM, Breck EN, Chan F, Lubchenco J, Menge BA (2005) Barnacle reproductive hotspots linked to nearshore ocean conditions. Proc Natl Acad Sci USA 102:10534-10539

- Mace AJ, Morgan SG (2006) Larval accumulation in the lee of a small headland: implications for the design of marine reserves. Mar Ecol Prog Ser 318:19-29

Mathews S, Bonser SP (2005) Life histories, ecological tolerance limits, and the evolution of geographic range size in Eucalyptus (Myrtaceae). Aust J Bot 53:501-508

Menge BA, Blanchette CA, Raimondi PT, Freidenburg T and others (2004) Species interaction strength: testing model predictions along an upwelling gradient. Ecol Monogr 74: 663-684

Minchinton TE, Scheibling RE (1991) The influence of larval supply and settlement on the population structure of barnacles. Ecology 72:1867-1879

> Minchinton TE, Scheibling RE (1993) Free space availability and larval substratum selection as determinants of barnacle population structure in a developing rocky intertidal community. Mar Ecol Prog Ser 95:233-244

Moran MJ (1985) Distribution and dispersion of the predatory intertidal gastropod Morula marginalba. Mar Ecol Prog Ser 22:41-52

> Murray-Jones SE, Ayre DJ (1997) High levels of gene flow in the surf bivalve Donax deltoides (Bivalvia: Donacidae) on the east coast of Australia. Mar Biol 128:83-89

O'Hara TD, Poore GCB (2000) Patterns of distribution for southern Australian marine echinoderms and decapods. J Biogeogr 27:1321-1335

$>$ Oke PR, Middleton JH (2001) Nutrient enrichment off Port Stephens: the role of the East Australian Current. Cont Shelf Res 21:587-606

> Olivier F, Tremblay R, Bourget E, Rittschof D (2000) Barnacle settlement: field experiments on the influence of larval supply, tidal level, biofilm quality and age on Balanus amphitrite cyprids. Mar Ecol Prog Ser 199:185-204

Otway NM, Underwood AJ (1987) Experiments on orientation of the intertidal barnacle Tesseropora rosea (Krauss). J Exp Mar Biol Ecol 105:85-106

Parsons P (1991) Evolutionary rates: stress and species boundaries. Annu Rev Ecol Syst 22:1-18

Pigott CD, Huntley JP (1981) Factors controlling the distribution of Tillia cordata at the northern limits of its geograph- ical range. III. Nature and causes of seed sterility. New Phytol 87:817-839

Qian PY, Thiyagarajan V, Lau SCK, Cheung SCK (2003) Relationship between microbial community and the attachment of acorn barnacle Balanus amphitrite Darwin. Aquat Microb Ecol 33:225-237

Roughan M, Middleton JH (2004) On the East Australian Current: variability, encroachment, and upwelling. J Geophys Res C 109:7003-7019

Roughgarden J, Gaines SD, Possingham H (1988) Recruitment dynamics in complex life cycles. Science 241: 1460-1466

Sagarin RD, Gaines SD (2002a) Geographical abundance distributions of coastal invertebrates: Using one-dimensional ranges to test biogeographic hypotheses. J Biogeogr 29: 985-997

Sagarin RD, Gaines SD (2002b) The 'abundant centre' distribution: To what extent is it a biogeographical rule? Ecol Lett 5:137-147

Sanford E, Holzman SB, Haney RA, Rand DM, Bertness MD (2006) Larval tolerance, gene flow, and the northern geographic range limit of fiddler crabs. Ecology 87:2882-2894

> Short AD, Trenaman NL (1992) Wave climate of the Sydney region, an energetic and highly variable ocean wave regime. Aust J Mar Freshw Res 43:765-791

Sprung M (2001) Larval abundance and recruitment of Carcinus maenas L. close to its southern geographic limit: a case of match and mismatch. Hydrobiologia 449:153-158

> Thiyagarajan V, Harder T, Qian PY (2002) Relationship between cyprid energy reserves and metamorphosis in the barnacle Balanus amphitrite Darwin (Cirripedia; Thoracica). J Exp Mar Biol Ecol 280:79-93

- Thiyagarajan V, Hung OS, Chui JMY, Wu RSS, Qian PY (2005) Growth and survival of juvenile barnacle Balanus amphitrite: interactive effects of cyprid energy reserve and habitat. Mar Ecol Prog Ser 299:229-237

> Thiyagarajan V, Lau SCK, Cheung SCK, Qian PY (2006) Cypris habitat selection facilitated by microbial films influences the vertical distribution of subtidal barnacle Balanus trigonus. Microb Ecol 51:431-440

Thorson G (1950) Reproductive and larval ecology of marine bottom invertebrates. Biol Rev Camb Philos Soc 25:1-45

> Tremblay R, Olivier F, Bourget E, Rittschof D (2007) Physiological condition of Balanus amphitrite cyprid larvae determines habitat selection success. Mar Ecol Prog Ser 340:1-8

> Underwood AJ, Fairweather PG (1989) Supply-side ecology and benthic marine assemblages. Trends Ecol Evol 4: $16-20$

> Underwood AJ, Denley EJ, Moran MJ (1983) Experimental analyses of the structure and dynamics of mid-shore rocky intertidal communities in New South Wales. Oecologia 56: 202-219

Vilchis LI, Tegner MJ, Moore JD, Friedman CS, Riser KL, Robbins TT, Dayton PK (2005) Ocean warming effects on growth, reproduction, and survivorship of Southern California abalone. Ecol Appl 15:469-480

Wisely B, Blick AP (1964) Seasonal abundance of first stage nauplii in 10 species of barnacles at Sydney. Aust J Mar Freshwater Res 15:162-171

> Woodward FI (1997) Life at the edge: a 14-year study of a Verbena officinalis population's interactions with climate. J Ecol 85:899-906

> Zacherl D, Gaines SD, Lonhart SI (2003) The limits to biogeographical distributions: insights from the northward range extension of the marine snail, Kelletia kelletii (Forbes, 1852). J Biogeogr 30:913-924 